\title{
Literacy, Teens, Refugees, AND SOCCER
}

\author{
Eric Dwyer and Mary Lou McCloskey
}

\begin{abstract}
This study examined the literacy development of teenage refugee boys in a one-month intensive summer literacy camp. The study intervention sought to abate literacy regression among language minority students in a suburban southern US city by combining physical training and promotion of literacy culture. Students experienced an intensive schedule of athletics and reading/writing workshops. Data were collected regarding student writing, reading proficiency, and dispositions toward literacy practices. Outcomes included increased expressed student enjoyment expressed for both reading and writing, especially for the experience of older students reading to younger peers. In addition, data indicated that summer literacy regression was largely avoided. However, reading proficiency level assessments foreshadow obstacles for students in achieving timely high school graduation. Finally, means used by mainstream teachers of assessing the literacy of refugee students, especially compared to assessments of proficient English-speaking students, are critiqued.
\end{abstract}

\section{Résumé}

Cette étude examine le développement de la littératie de jeunes adolescents réfugiés lors d'un camp d'été intensif d'alphabétisation d'une durée d'un mois. L'intervention examinée visait à freiner la régression de la littératie chez les étudiants de minorités linguistiques d'une banlieue du sud des États-Unis, en combinant l'entraînement physique et la promotion de la culture écrite. Les étudiants ont suivi un horaire intensif d'activités athlétiques et d'ateliers de lecture et d'écriture. Les données recueillies se rapportaient à l'écriture, les compétences de lectures, et à la disposition aux pratiques de la littératie des étudiants. Les résultats incluent l'augmentation du plaisir de la lecture et de l'écriture exprimé par les étudiants, en particulier au sujet de l'expérience qu'ont faite les étudiants plus vieux de lire aux plus jeunes. De plus, les données indiquent que la régression de littératie propre aux vacances estivales avait été évitée. Néanmoins, les évaluations des compétences de lecture laisser présager que les étudiants rencontreront des obstacles dans l'obtention de leur diplôme d'études secondaires dans les temps prévus. Enfin, on y fait la critique des moyens que les enseignants réguliers emploient pour évaluer la littératie des étudiants réfugiés, surtout en comparaison avec l'évaluation des étudiants de langue anglaise.

\section{Introduction}

Just outside Atlanta, a summer camp is conducted for adolescent boys who are avid soccer players. However, this is no ordinary camp. It is intended for refugee boys from Afghanistan, Bosnia and Herzegovina, Burundi, Cuba, the Democratic Republic of the Congo, Ethiopia, Eritrea, Iraq, the Karen region of Burma, Kosovo, Liberia, Nepal, Rwanda, Sierra Leone, Somalia, and Sudan, and has important literacy goals. Many of these young people have experienced the violence of war and separation from parents, relatives, and mentors. Various relief agencies have helped these students and their families find a suburban community in the southern United States, one with a warm climate, some job opportunities, good public transportation, and underused apartments. Camp fees are paid by donors, and teachers are volunteers. The authors, both professionals in English language teaching, were invited to volunteer as instructors and to report to the organization's donors on the boys' literacy development during this summer literacy camp.

The boys belonged to local soccer teams working with the same coach. The purpose of this collective was not only 
to provide a means for boys to play organized soccer but also to use soccer as a springboard to advance the boys' academic growth and potential. In order to participate, boys followed closely enforced restrictions, including no smoking, no drugs or alcohol, no missed practices, no gangrelated activity, and no grade average lower than a $\mathrm{C}$. The coach understood, however, that many students who were new to English might not maintain the $\mathrm{C}$ grade without extracurricular support; thus, English language development and reading were partnered with soccer practice. During the school year, every ninety-minute soccer workout was followed by a ninety-minute tutoring session. The coach instituted additional requirements for acquiring vital uniform pieces the boys needed to play in any game: regular attendance at practices and tutoring sessions and reading a minimum number of books on their own. This, along with transportation support, enabled the boys, whose families could rarely afford uniforms or other fees, to play in soccer leagues as long as they were attending practice and studying, reading, and working in school classes, including English.

\section{Refugee Youth and Literacy Development}

Numerous agencies allude to right of refugee youth to attain education and aspire toward higher education (e.g., the 1951 Refugee Convention ${ }^{1}$ and the UNHCR in its education policy ${ }^{2}$ ). Furthermore, the Refugee Act of 1980, which initiated the Federal Refugee Resettlement Program, states, "The Secretary of Education is authorized to make grants, and enter into contracts, for payments for projects to provide special educational services (including English language training) to refugee children in elementary and secondary schools where a demonstrated need has been shown." 3 While such sentiment may be heralded, none of these policies refers in detail to how to educate refugees to enable them to ultimately attend college, even if they are fortunate enough to gain access to ongoing quality K-12 schooling. As such, the documents fail to indicate that educational approaches for refugees, even when they gain access to mainstream schooling, might need to be different from those used with their new peers.

In the US, in an effort to track how students progress through their educational careers and into post-secondary education, state departments of education are charged with tracking the number of students who pass standardized examinations regarding reading development. ${ }^{4}$ In other words, there exists an underlying assumption that students' fundamental ability to achieve graduation and matriculation into college depends on their ability to read and write in sophisticated ways. These departments of education then determine which schools are successful in helping students attain predetermined literacy levels. Among these assessments are calculations based on student ethnicity, disability, and socio-economic status. Another such calculation is derived for English language learners (ELLs), a student body often constituting students with limited access to formalized education (known as limited formal schooling, or LFS), students with interrupted education (usually students of migrant families who move from one school to another after short periods of time), and refugees. However, beyond the labelling of ELL, these additional descriptions of students are not teased out in state-reported data. As a result, in the US and indeed worldwide, little is known with direct respect to literacy development of refugee students.

\section{Research in ELL Literacy Development}

English language teachers currently use a number of tools to assess students' English language proficiency. The most commonly used assessment scale for English learners in the US today is the Assessing Comprehension and Communication in English State-to-State for English Language Learners (ACCESS for ELLs) based on the framework and standards of World-Class Instructional Design and Assessment (WIDA). ${ }^{5}$ At present, thirty-two states and one territory of the US use ACCESS to assess whether students should be placed in a preliminary English as a Second Language (ESL) class or in a mainstream class, for level placement in classes, and to inform instruction. Once students graduate from ESL to mainstream, they are then measured against native speakers on standardized exams and other reading assessment measures designed specifically for proficient or native English speakers (NESs).

In mainstream classes, teachers must keep track of students' reading proficiency. To accomplish such, teachers use reading inventories - a battery of reading passages rated by grade level. Since NES-based research has shown that native speakers' accurate pronunciation of words when asked to read them (also known as decoding) correlates strongly to their comprehension level, ${ }^{6}$ teachers ask students to read these graded passages aloud, and teachers note misprononunciations. Students are then determined to belong to the proficiency level corresponding to the graded passage where they start making a mistake or two.

The implementation of NES-based surveys (such as the Flesch-Kincaid grade level index ${ }^{7}$ ) for ELLs has been critiqued, with suggestions that concern for syntactic complexity, rhetorical organization, propositional density, ${ }^{8}$ and word frequency are often overlooked when teachers assess their students' reading proficiency levels. ${ }^{9}$ In other words, many ESL teachers know that some students can decode words accurately without knowing what they mean. Additionally, these critiques point to the concept of academic language-i.e., linguistic skills specifically needed to 
master schooling and textbooks ${ }^{10}$-as an integral feature of ELL reading development that is often disregarded by NESbased reading researchers and mainstream teachers in their lesson plans. However, in spite of the critiques, to our knowledge, no full-scale study had been developed showing the degree to which an NES-based reading assessment helped or hindered literacy development in new English readers, let alone a study directed toward refugee students.

The researchers had noted that their own teacher trainees, who had numerous experiences observing primary and secondary level classrooms, reported that often good-hearted mainstream teachers, considering ELLs to be capable and bright, treated both NESs and ELLs similarly when using cooperative learning practices. ${ }^{11}$ Treating all students equitably is, of course, laudable; however, it may not be sufficient. DeJong and Harper have documented the importance of teachers' recognition that learners of a new language need specific support to focus on particular linguistic hurdles ${ }^{12}$ and that classes and programs should be differentiated so that students of similar ages or language proficiency levels can study together as appropriate. In practice, however, some teachers with positive dispositions might not be grouping students of similar language abilities so that teachers and students themselves can bolster their language development in manageable ways. ${ }^{13}$

Additional concerns arise when students enter school at secondary school ages. The US school system navigates students through two or three years of middle school or junior high school (generally) and four years of high school. However, research suggests that newcomers may need on the order of seven years or more to master so-called academic language and perform like native-language peers. ${ }^{14}$ Thus, any newcomer into a secondary school with little English faces a daunting challenge, as do these students' teachers. Yet very little research has been conducted on reading development of ELLs in secondary settings and the scope of this challenge is not fully understood. In other words, even when using NES-based surveys, we know little with respect to secondary students with limited formal schooling, including their overall comprehension rates or their writing development.

While little is known regarding secondary ELLs' reading development, research has indicated slow academic advancement due to socio-economic status, both in minority children ${ }^{15}$ and English learners. ${ }^{16}$ In addition, research has shown that some immigrant students may forget some of the English they've learned because they don't practice it over summer break, a phenomenon known as summertime slack. ${ }^{17}$ In other words, refugees who already often come into school with inconsistent periods of education find summer break an additional interruption from the consistent instruction and exposure needed for students to attain the academic language that can support them toward high school graduation.

\section{Soccer Plus Literacy Program Goals}

The coach had observed that the refugee students had little to do in the summer. Most parents worked, some at two or more low-paying jobs. The boys' families didn't have financial support to send their kids to camps, had little time after work to spend with them, and were often English learners themselves who didn't have the skills to help their children with language development. The coach, concerned about a three-month lull in the boys' language development, began the first year by holding a short summer literacy camp. She instituted a reading chart and challenged the boys to read a number of books. The coach found the camp moderately successful, but she wished to improve the camp in both length and quality for the second summer. As a result, she asked the authors to help with the year-two four-week summer camp.

In conceiving language goals for the program, two major tenets were promoted-accentuating the positive (using heightened motivation and appropriate instruction to enhance learning) and defying the negative (overcoming the challenges of interrupted schooling, summertime slack, and less effective instruction). ${ }^{18}$ Soccer was a valuable catalyst for accentuating the positive, as correlations have been cited between physical activity and academic progress. ${ }^{19}$ The coach's observations and assumption, supported by the research of Walker and of Singh et al., was that soccer could serve as motivator, energizer, and self-esteem builder. ${ }^{20}$ Accentuating the negative is the students' experience of the issues of tracking. Because students are language learners or have interrupted education, they have low entrance test scores and are frequently placed in slower-paced, lowertracked sections and sequences in school. Unfortunately, students have a difficult time moving out of those levels and may not end up in a program that adequately prepares them for higher education. ${ }^{21}$ The researchers designed a program to ameliorate summertime slack through treating all students positively and, while accommodating language levels, challenging them cognitively as if they were tracked into the highest-level tracks. This approach aligned well with those of the coach and the program.

With these caveats in mind, the following notions of second language development were implemented:

1. using what works to create long-term, self-initiating learners, ${ }^{22}$

2. fostering reading improvement through sustained silent choice reading, ${ }^{23}$

3. developing self-expression and cultural representation through process writing of personal narratives, ${ }^{24}$ 
4. developing science concepts and promoting environmental sustainability and responsibility through study of water ecology, 25 and

5. treating students as authors, and authors as readers. ${ }^{26}$ Such an approach was established in an effort to give refugee students voice ${ }^{27}$ which could viably demonstrate students literacy progression, as well as their potential contributions to the community.

Thus, the authors and leaders program for the academic camp that included sports, reading, and writing made use of activities designed to be appropriate to students' proficiency levels and age. We wanted this program to illustrate how literacy development can be motivating, engaging, meaningful, and purposeful though we had only one month of intervention.

\section{Research Objectives}

In sum, a group of refugee boys playing soccer needed help with their English and academic development. Their coach also desired accurate data showing the educational advancement achieved by the program to report to donors. And finally, we found opportunities within this experience to share evidence on refugee youth literacy development that had not yet been reported. At the basic level, there was a pressing desire to avert summertime slack in the boys' language development. Equally important, however, was to determine if teachers and students could parlay students' motivation for soccer into motivation for their own linguistic and academic advancement. In other words, while enjoying soccer, could the students enjoy and improve their literacy? Answers to these questions could not only serve as important information for the program donors, but also be useful information for teachers of refugees and administrators of refugee programs, particularly as they themselves report progress in reading comprehension levels and writing development to students' families, administrators, and policy makers.

\section{Methodology}

Setting: The Summer Camp Structure

The coach, other team organizers, four AmeriCorps Volunteers, and seven teacher volunteers comprised the camp staff. The program had thirty-five student participants, ranging from age nine to seventeen, with an average age of 13.7 years. (Many refugees do not have birth certificates because of such factors as war, cultural differences, and refugee camp record-keeping. The age levels were the best we could determine based on parent reports and immigration information.) The camp team met before the program began and interacted regularly during the program, both through almost daily meetings and email interactions. Teachers were asked to plan their sessions with learners to include activity-based communicative language learning, content-based language learning, balances between reading and writing, and the development of language skills in context. ${ }^{28}$ The following daily routine was conducted:

- Book club-where we focused on independent reading, shared reading, and language experience, using authentic texts chosen for interest, relevance and learner proficiency level;

- Journals-where we asked students to begin each day by writing in a journal, engaging with teachers or other students in informal written interactions, keeping content and communication as the primary goal, but never using this activity as a means of error correction;

- Writing for publication-where we examined intricacies of writing-including correction of spelling, grammar, and style-on the way to establishing some sort of community book;

- Green Club-where students examined their role in environmental issues, building this summer upon the themes of "reduce, re-use, and recycle," as well as water cycle and water monitoring;

- Arts-where students explored media and re-interpreted content;

- Inter-class teaching and learning-where students worked with other students through tutoring and book sharing;

- Fitness-where students participated in karate, yoga, and stretching;

- Self-monitoring skills-where students were overtly asked to participate, contribute, support, and initiate; and

- Field trips-usually organized around the environment theme of the camp.

In addition, a daily schedule was set:

\begin{tabular}{ll}
\hline Time & Activity \\
\hline $\begin{array}{l}\text { 10:00-10:30 am } \\
\text { 10:30-12:00 noon }\end{array}$ & $\begin{array}{l}\text { Workout 1 } \\
\text { Small group class time, including } \\
\text { Book Club, journals, and content } \\
\text { activities }\end{array}$ \\
$\begin{array}{l}\text { Workout } 2 \\
\text { 12:00-12:30 pm }\end{array}$ & $\begin{array}{l}\text { Lunch } \\
\text { 1:00-1:30 pm }\end{array}$ \\
$\begin{array}{c}\text { 1:30-3:00 pm } \\
\text { Some weekday } \\
\text { afternoons }\end{array}$ & Art Club or Green Club \\
Friday afternoon & Field trips to content-related sites \\
\hline
\end{tabular}




\section{Data Collection}

Greene and Caracelli write of a dialectical approach to mixing methods in research practices for achieving both logical and political means. ${ }^{29}$ As the researchers also served as two of the teachers in the summer camp, this approach was embraced within the framework of a participant action research project. ${ }^{30}$ Since the research itself would be short, only four weeks in duration, the usual recursive nature of both dialectical and action research practices would be truncated, leaving the results here only to be judged for subsequent revisions of program structure. Nevertheless, since understanding the degrees of student enjoyment and literacy development were the most immediate goals of the research, a dialectical combining a qualitative analysis of students' verbal answers and quantitatively based assessment of student progress was employed. As a result, the following steps were applied in this research:

- a qualitative analysis of student journal writings as well as in-camp compositions;

- a learner reading survey to be given pre/post;

- an NES reading assessment, using an Informal Reading Inventory, to be given pre/post;

- a rubric-based writing assessment to be given pre/ post; and

- a program listserv for teachers and organizers to share daily notes, observations, and ideas.

\section{Student Journal Writings}

At the core of examining the students' experience with literacy was having students develop portfolios. This enabled us to include qualitative analysis of students' daily journals, as well their creations manifested during a month-long book project. It was thought that diary entries and actual examples of student work would most likely yield the most in-depth descriptions of the boys' educational experience. ${ }^{31}$ Data from these journals were analyzed with an inductive content analysis approach to identify key themes. ${ }^{32}$

\section{Learner Reading Survey}

In an effort to capture student attitudes toward reading and how they might change over a month, a learner reading survey was devised. As a foundation, a reading attitudes survey from the Literacy Trust in Great Britain ${ }^{33}$ was selected and altered to meet the camp's needs. Because most students would have language proficiencies precluding them from completing the entire survey, several questions were paraphrased grammatically, while (hopefully) maintaining meaning. ${ }^{34}$ Most learners were asked to fill out surveys on their own; however, several learners of lower language proficiency gave oral answers with researchers taking as detailed notes as possible.
The reading survey consisted of twenty questions, of which three directly applying to research goals are reported here:

- How much do you enjoy reading?

- How often do you read outside of school?

- Do you like reading to younger children?

\section{NES Reading Assessment}

A desired consequence of this research was to be able to converse with mainstream teachers about research regarding L1 reading inventory use for L2 proficiency level decision making, basing comment on actual experience by having implemented such with secondary refugee students. Thus, Lois Bader's Reading and Language Inventory ${ }^{35}$ was implemented as our baseline for establishing reading grade levels. From this inventory, we chose two aspects-word lists and reading passages-both of which would help establish a reading level for each student. First, we counted pronunciation errors the students made when reading levelled ten-word lists aloud. We had to take special efforts in the training to establish which errors in reading word lists were caused by learner accents and which by lack of knowledge of the words. The grade level was established when the student made no more than two errors in reading words from that list. We then asked students to read some levelled passages written especially for children. Given the likelihood that students would out-decode their comprehension, ${ }^{36}$ we started with a passage marked at a grade one level lower than where they scored on the word reading assessment. For example, if a student had two errors on the fourth grade vocabulary read-aloud list, we started him with a third grade reading passage. Students started by reading the passage aloud. If a student had any read-aloud errors in his oral reading, we asked comprehension questions for that passage. The Bader instrument includes prepared questions, which we asked in the following order: first unprompted; then questions for memories not mentioned; then an interpretive question. If students correctly answered the required number of questions to pass the level, we moved to the next level. If, however, frustration level was reached in the oral reading, we gave the child a second chance to read the passage silently before administering questions. If the student achieved the minimum number of accurate responses on the comprehension, we continued to the next level with oral reading, then silent reading and comprehension. However, when a student did not achieve the minimum number of accurate responses on the comprehension questions, we concluded the assessment and noted the grade level of the corresponding passage.

Carrying out such a procedure entailed a conundrum: that examining the program by comparing statistical means 
would entail comparing a wide range of ages and proficiency levels to a single norm-a notion we found inappropriate. However, camp administrators explained that local stakeholders, including donors to the teams, would likely wish to look at publicly canonized numbers-namely English reading grade levels and high stakes test scores, i.e., scales designed for NESs. As a result, any quantitative research design involving pre- and post-data would most likely result in insignificant result-set here to a p-level of .05-due to the short four-week program schedule of the program. Furthermore, any dedication to levels of significance with respect to decision making might prevent making reasonable decisions for students with outlying results. Thus, in an effort to use quantitative analysis as descriptively as we could, we opted to use box plots and examinations of 95 percent confidence interval data, showing likely ranges of literacy development among the students.

\section{Writing Assessment}

For our student writing assessment, we prepared parallel pre/post prompts administered at the beginning and the end of the summer program. Teachers asked the boys to write for no more than ten minutes on the topics, which were preselected and discussed by the participants. To be parallel with our approach to reading assessment and in light of the demands for use of an NES-based analysis, we opted to adapt a noted writing rubric deigned by Ruth Culham called the $6+1$ Writing Rubric. ${ }^{37}$ Culham emphasizes the following seven facets of writing to help learners to be engaged, practiced, and advanced: ideas, organization, voice, word choice, sentence fluency, conventions, and presentation. Student output was graded by two outside raters, who did not know learners or whether the sample was pre or post. Our prompts and adapted rubric may be found in Appendix A.

Writing samples were collected at the beginning and the end of the camp. Three instructors with credentials in TESOL but not involved with the camp evaluated the writings, implementing the Culham-adapted $6+1$ rubric. They attended an evaluation session which began with a short training session to increase evaluator consistency. A Fleiss kappa inter-rater reliability rating was calculated, registering a .60 coefficient, indicating borderline "moderate" to "substantial agreement" on Landis and Koch's scale defining such coefficients. ${ }^{38}$ The evaluators gave scores of 1,2 , or 3 for each of the seven categories, thus eliciting an overall writing score range of 7 to 21 .

\section{Teachers' Notes}

Finally, we asked teachers to provide notes and observations of their classes each day on a listserv. Teachers were encouraged to interact with one another regarding any questions, experiences or concerns. Data from these listserv entries were analyzed with an inductive content analysis approach such that key trends might be determined. ${ }^{39}$

\section{Outcomes}

Students' Expressions of Their Interest in Literacy

The boys engaged in a number of writing projects over the month. One project was poetry writing. This activity sparked quite a flurry of positive experiences. The lowest proficiency level group, inspired by Nikki Giovanni’s “Two Friends," 40 a composite group poem referring to clothing, soccer uniforms, sport trademarks, wristbands, and their relationships:

Our class has:

Two pairs of jeans,

Three pairs of shorts,

Two shirts with number seven,

Three swooshes,

Five wristbands,

Figure 1. Radar chart regarding pre- and post-camp responses to the question, "How much do you enjoy reading?"

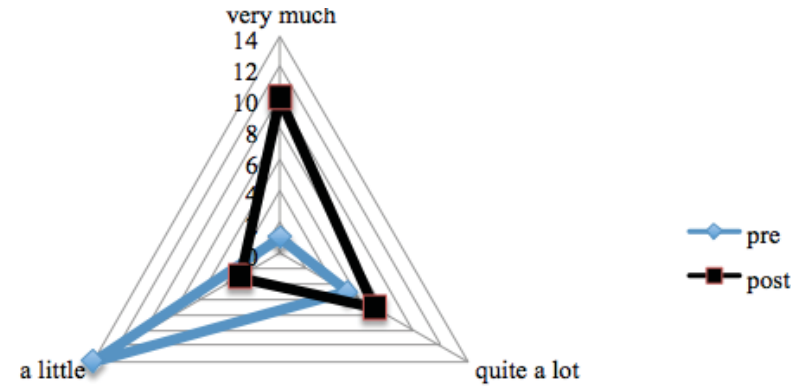

Figure 2. Radar chart regarding pre- and post-camp responses to the question, "How often do you read outside school?"

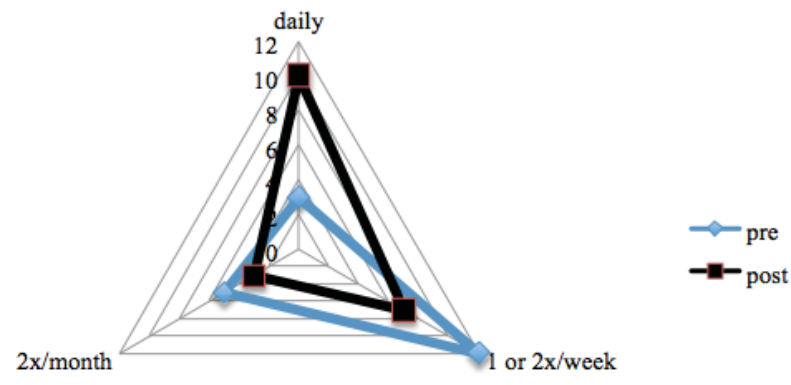

Ten sandals and two cleats, One chain, one watch, One favorite sport-soccer-and

One good family friendship 
In another group, a student of higher language proficiency constructed a poem called "In Love with a Ball" in the format of a Shakespearian sonnet, where he asked the ball how it felt when his cleats crossed his face. In one class where a more advanced group attempted haiku, one student wrote a poem from the perspective of the pitch, a selfish turf desiring cleats but instead receiving faces. The students provided additional evidence in diary entries that the camp's writing classes provided additional enticement to attend. One student expressed that he was having fun writing haiku. Another said that poetry writing was one of the "funnest" things he'd done that summer.

Such comments were later supported by comments from the Literacy Trust adapted survey of reading attitudes. Twenty students responded at the beginning and end of camp to this question: "How much do you enjoy reading?" Notably, as evident in Figure 1, reporting of reading enjoyment among the athletes had increased.

We worked tenaciously to find books students could enjoy. Gratifyingly, students reported a tremendous upswing in reading enjoyment over one month, increasing "very much" ratings from 1 to 10, and decreasing "a little" ratings from 14 to 3 . We found the study more remarkable since some of the students had already gone through a literacy camp the previous year, though without the implementation of these theoretical foci. The students may have been somewhat

Figure 3. 95\% confidence interval of students' reading grade level, pre- and post, over a 4 -week period, as determined by Bader Reading Inventory

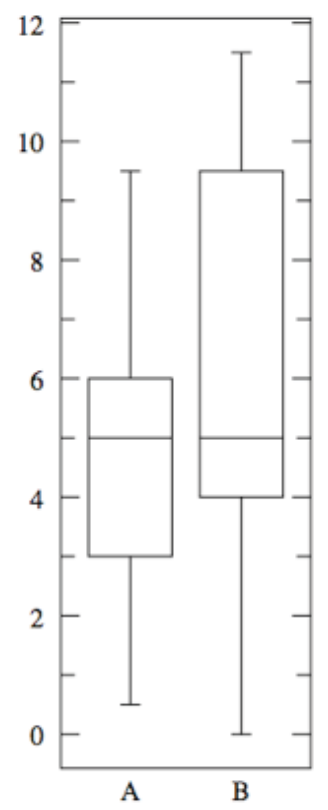

convinced of the importance of reading; however, we were pleased to see such an upswing in students' saying they actually enjoyed the pleasure reading activities.

We also asked the question, "How often do you read outside of school?" Initially, three students responded with "daily"; on the post assessment the number increased to ten students. We of course wondered if students could maintain this newly attained penchant for reading over the regular school year.

One enlightening finding from the Literacy Trust adapted survey was that seventeen of twenty students reported on the pre-test that they liked to read to younger kids. Upon noticing this result, daily opportunities were built into the schedule for older students to read to younger kids. The learners enthusiastically prepared writings and read to each other during free reading and classroom exercises.

\section{Use of the Bader Reading Inventory}

As we worked with students for only four weeks, we were skeptical with respect to obtaining significant differences in reading results using the Bader reading inventory. The pretest mean grade level measured by this group was 4.60 $(\mathrm{SD}=2.32)$, meaning that the average grade level for these students, as measured by this inventory, was in the middle of the fourth grade. Considering students' ages averaged well into eighth grade, we then framed our thoughts that users of such an inventory might register these students as a group approximately four years behind their peers in English reading ability. More alarmingly, no student who attended high school registered a high school reading grade level, indicating that learners trying to acquire sufficient English to graduate or attend college face a mountain of work to be conquered in a very short time.

After twenty literacy camp days, learners tested at a mean grade level of $5.62(\mathrm{SD}=3.16)$ on the Bader scale. Did students make an overall gain in a month? We do not claim such $(\mathrm{t}=-$ 1.02; $\mathrm{SD}=2.77 ; \mathrm{p}=.24)$. However, the 95 percent confidence level plot (1) indicates no overall Werner-Smith and Smolkintype summertime regression by the students, and (2) hints that achieving significant results is probable should such robust reading exercise continue.

Table 1. Student reading grade level, mean and 95\% confidence interval, as determined by Bader Reading Inventory

\begin{tabular}{lll}
\hline & Pre & Post \\
\hline mean & 4.60 & 5.62 \\
SD & 2.32 & 3.16 \\
$\begin{array}{l}\text { 95\% confidence } \\
\text { interval }\end{array}$ & 3.38 thru 5.82 & 4.40 thru 6.84 \\
range & 0.50 thru 9.50 & 0.00 thru 11.50 \\
\hline
\end{tabular}




\section{Decoding vs. Comprehension}

In administering the Bader inventory, we had learners read a graded list of words to determine initial placement on the reading, then had learners read successively more difficult passages. We had suspected that in a single assessment, the difference between students' grade level pertaining to decoding a list of words and their ultimately determined reading comprehension levels would be significant. This however was not the case ( $\mathrm{t}=1.09 ; \mathrm{SD}=2.27 ; \mathrm{p}=.27)$. As a result, at least in terms of a viewpoint across all proficiency levels from novice to superior, decoding does seem to predict to some degree English learners' ability to comprehend text. Nevertheless, an analysis of the 95 percent confidence levels comparing decoding and comprehension is compelling; such data indicate that when accounting for outliers, a good number of students seem to be decoding at levels a grade or two higher than they are actually comprehending.

If we observe that when a majority of our students score as decoding one or two grade levels higher than their com-

Figure $4.95 \%$ confidence interval representation of student reading grade level score as determined with specific respect to pre-test decoding and overall comprehension through the Bader Reading Inventory

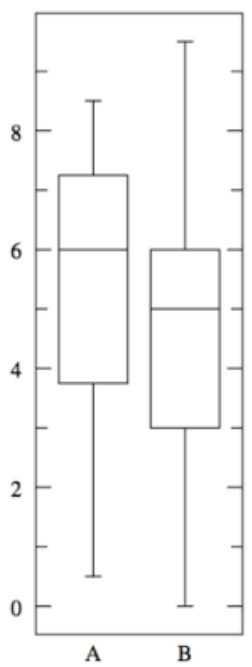

$$
\begin{aligned}
& \text { Reading grade level: } \\
& \text { A = word list reading; } \\
& \text { B = overall comprehension of passages }
\end{aligned}
$$

prehension assessments, we must also consider that if only NES assessments like this are used, teachers might believe their English learners to be better English readers than they actually are. An extreme example of this occurred with one newly arrived Cuban athlete, a student who was highly literate in Spanish and was able to use his knowledge of Spanish phonics to pronounce most words on the Bader word list, yet unable to answer most comprehension questions.
Table 2. Comparison of student reading grade level scores, mean and 95\% confidence level, as determined with specific respect to pre-test decoding and overall comprehension through the Bader Reading Inventory

\begin{tabular}{lll}
\hline & $\begin{array}{l}\text { word lists- } \\
\text { decoding level }\end{array}$ & $\begin{array}{l}\text { passages- } \\
\text { comprehension } \\
\text { level }\end{array}$ \\
\hline mean & 5.36 & 4.60 \\
SD & 2.23 & 2.32 \\
$\begin{array}{l}\text { 95\% con- } \\
\text { fidence } \\
\text { interval }\end{array}$ & 4.36 thru 6.36 & 3.59 thru 5.60 \\
range & 0.50 thru 8.50 & 0.00 thru 9.50 \\
\hline
\end{tabular}

These data, however, do not distinguish among grade levels or proficiency level, and there are too few students to establish grade levels in this research design. Hence, we would predict that those at beginning levels might actually have similar decoding and comprehension-that approaching zero-because the students are just getting started. Then at intermediate and lower advanced proficiencies, we might actually see greater differences between decoding and comprehension. Theoretically one's knowledge of the language's orthographic system should then level off as one adds comprehension skills; hence, in more advanced proficiency levels, a student's comprehension could conceivably approach or even catch up to one's decoding ability.

Figure 5. 95\% confidence interval representation of pre- and post assessments of students' overall writing, across a 4-week period, based on Ruth Culham's 6+1 Writing Rubric (range of score: $7-21)$

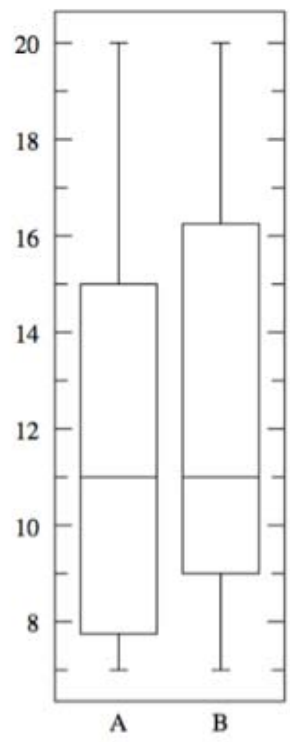

overall writing scores (range 7-21):

$\mathrm{A}=$ pre $; \mathrm{B}=$ post 
Table 3. Comparison of pre- and post assessments, mean and $95 \%$ confidence intervals, of student writing samples, across a 4-week period, based on adaptation of Ruth Culham's $6+1$ Writing Rubric

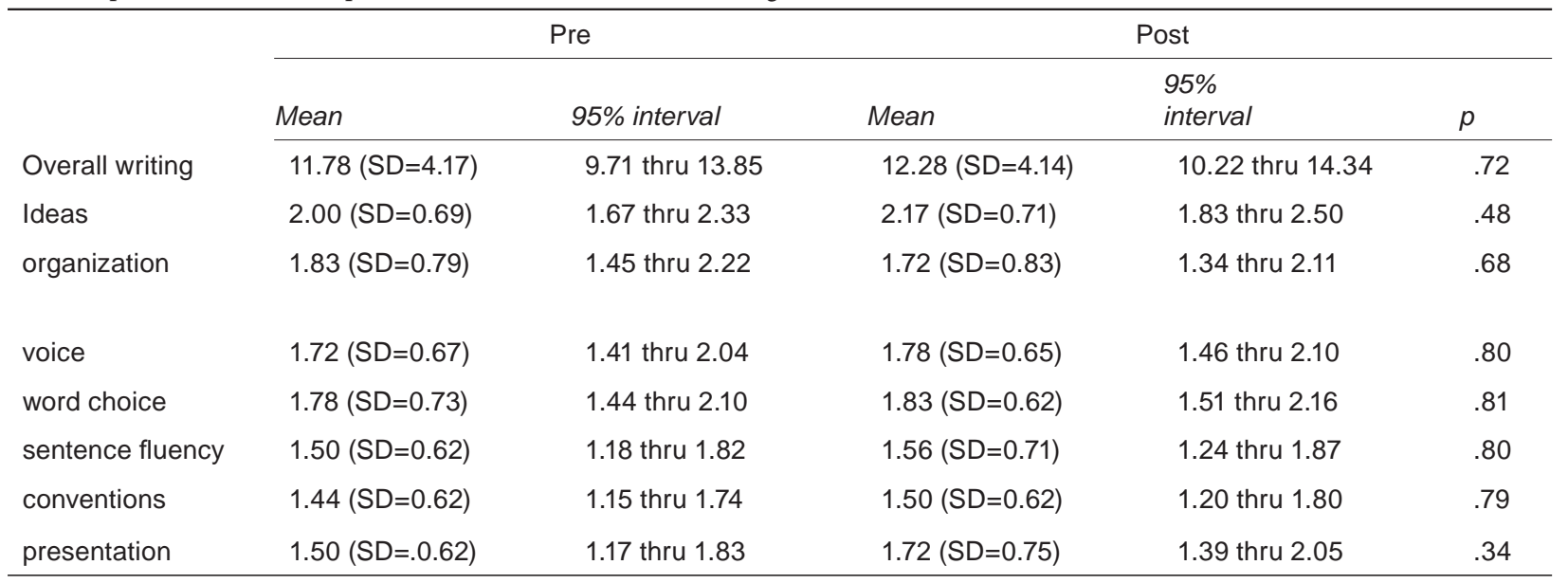

\section{$6+1$ Writing Rubric}

An analysis of the results indicates that, as expected, we did not achieve statistically significant improvements in overall writing skills ( $\mathrm{t}=-.36$; $\mathrm{sd}=4.15 ; \mathrm{p}=.72)$. Both pre- and postmeans indicate that

- most students were not currently able to write in English to a level many language arts teachers might see as "average";

- we cannot claim that gains were made with respect to the students' writing abilities; however, we can claim that Werner-Smith and Smolkin's notion of summertime regression was largely avoided;

- we can be pleased that we gave the boys opportunities to express their own ideas in writing, as the ideas assessment hints at progress;

- we offered writing opportunity for students to focus on formal composition structures, as suggested in the presentation results;

- subdivisions in writing progress over lower proficiency levels were not captured in the Culham-adapted rubric, most likely masking any possible progress students of lower proficiency level might have made; and

- overall writing improvement is indicated by the qualitative results of student compositions and poetry.

\section{Teacher Observations}

Most teachers in the program were diligent with respect to offering comments and diary entries in an online conversation over the month. Overall, there was satisfaction expressed with the reading and writing, particularly because they found that pre-class meetings were helpful in fostering teacher collaboration. Teachers felt successful in helping students choose books and in conducting prewriting brainstorm sessions. Most notably, teachers stated that students were paying attention to the environment-related themes from the field trips, reporting that students discussed and referred to the themes reduce, re-use, recycle almost daily.

However, several issues did emerge with regularity over the course of the month:

1. Health issues were noted, namely eyesight and hearing. Teachers suspected that some students might need glasses or hearing aids and requested that camp leadership seek exams for the learners, a request which was granted.

2. Teachers and camp organizers were pleased that the boys were able to have a rather large choice of free reading books. The degree of choice was much larger than in the previous camp and vastly larger than would have been possible without the camp. However, the breadth of choices was clearly not wide enough and teachers experienced difficulty in finding age-appropriate books corresponding to non-native language proficiency levels and cultural relevance.

3. With respect to writing, teachers felt, much as O'Malley and Chamot suggest, that learning strategies (strategies for learners to address learning challenges and independent study) needed to be specifically incorporated into lesson plans.41 Teachers suggested showing students how to take notes as an area of emphasis in future literacy camps.

4. Teachers were somewhat surprised to see how much students, especially the older ones, appreciated teacher read-alouds during the morning "Book Club."

5. Not to anyone's surprise, teachers noted a number of pronunciation issues. Those requiring the most attention were the sound of "r" and both the voiced and voiceless "th's." as well as dropped final syllables and final "-ed's". These are common issues with new learners of English from students' language groups. Teachers reported in the online diaries how they modelled tongue placement when making difficult sounds in their 
classes, and introduced tongue twisters that provided practice with these sounds in a non-threatening way.

6. Students reported difficulties with peers in their neighbourhoods, including bullying and theft. This issue actually caused the most teacher concern. One conversation included a suggestion of involving police; however, both students and program leaders suggested that this might be ineffective or even dangerous since the students still had to live in the same neighbourhood as their abusers.

\section{Conclusions}

Naturally, we wish we had had more time to do more. Certainly we fancied beginning literacy lessons earlier than 10:00 a.m. so that we could spend even more engaged time reading, writing, and conversing on academic content such as science and social studies. Nevertheless, in retrospect, we felt positive with respect to our goals. We found we could easily treat students as top learners-giving them responsibility for their learning, having them make choices, including their culture in learning activities, tutoring younger learners, and developing publishable writing-while tailoring their lessons to their proficiency level needs. In the process, in spite of a lack of statistical significance, we felt optimistic that students were making promising gains with respect to their literacy, particularly in reading and avoiding summer language regression with these students. And most clearly, our survey indicated that we successfully promoted positive attitudes toward reading and writing.

Of course, given the short-term research design, we can't claim that there is a correlation between the positive treatment of the students and their reading gains, as current quantitative practice would preclude us from doing so within such a short timeframe. We learned that, even for ELLs, assessing decoding can help us understand to some degree how English learners are comprehending their new language. However, we also learned that progress ELLs make with respect to decoding and comprehending is unlikely to be congruent to that of NESs.

More importantly, however, we learned that the reading levels of the refugee students in our group lagged approximately four years behind those of their NES peers. In fact, no high school student in the program began the summer at high school reading levels. (The accuracy of such consideration should be tempered as this assessment gives us no knowledge of learners' proficiency in their home language. Furthermore, to our knowledge, to date we know of no multilingual reading inventory that considers both the students' home languages and target language for the languages of our learners.) While there are enough data to warrant optimism that students were progressing in their reading, we left the summer worrying about the students entering their school year. We could not foster statistically significant change in students' reading ability in our month together, even in an intensive setting where literacy is emphasized for four to six hours each day. Thus, such results portend a monumental task students will likely encounter over the regular school year. For students already in high school, hoping to graduate within one to three years and desiring college matriculation, raising reading proficiency four grade levels or more seems overwhelming and unlikely.

We observed that refugee student intellect, creativity, and cleverness were much more evident through the qualitative inquiry. In fact, an analysis of student progress levied only through quantitative means would have skipped the students' passion, poetry, humour, or intrigue in the subjects and assignments they experienced. The statistical approaches toward describing student progress did not capture the emotion or artistry exhibited in the students' writing, nor did they yield descriptions of the teachers' passion for these students. In addition, the quantitative design was not sensitive enough to register progress over four weeks. As a result, we learned that in future research designs we will want to address more detailed attributes of progress attributable to new English learners working through the beginning stages of their language learning. Our choice of an NES-based writing assessment tool taught us why mainstream teachers may not notice progress in their English learners' writing, thus potentially exposing refugee children to unwarranted criticism for not making any measurable progress. Thus, we may need to (1) combine established ELL-focused assessments including detailed descriptions of writing progress at lower proficiency levels-with NES assessments, such that all students, NESs and ELLs, are included in data-driven descriptions of students' progress; and (2) insist that qualitative analysis of refugees' writing examine the content and underlying affect expressed in their compositions.

Furthermore, international refugee organizations may now address reading and writing as part of education related policy, noting any of the following issues:

- Regular and persistent attention to literacy-based activities may be vital in helping refugee students attain higher education opportunities;

- Programs should account for the fact that refugee students, especially those of secondary school ages, may face daunting challenges in achieving English language proficiency levels sufficient for graduation in a timely manner;

- Current NES-based practices can misdirect teachers in their assessment of refugees' literacy proficiency; thus, assessment procedures specific to ESL students should be promoted; and

- Refugee students bring stories and experiences that can broaden and enlighten all students' education.

The soccer teams are made up of boys who have lived through unspeakable experiences, and yet the contributions these students may make to any mainstream literacy setting are immediately evident. Inappropriate assessment policies in the US could easily and dangerously foster apathy toward a group of students who merit tremendous attention, not only for the sake of their own prospects for graduation and college but also for the advancement and enrichment of their teachers and native 
English speaking peers. While the summers with the refugees left us cherishing the students, we also professionally caution our colleagues to critique any analysis of ELL progress that doesn't include either ELL-specific considerations, especially at lower proficiency levels, or qualitative inquiry regarding student ingenuity.

Rubric for Six Traits of Writing

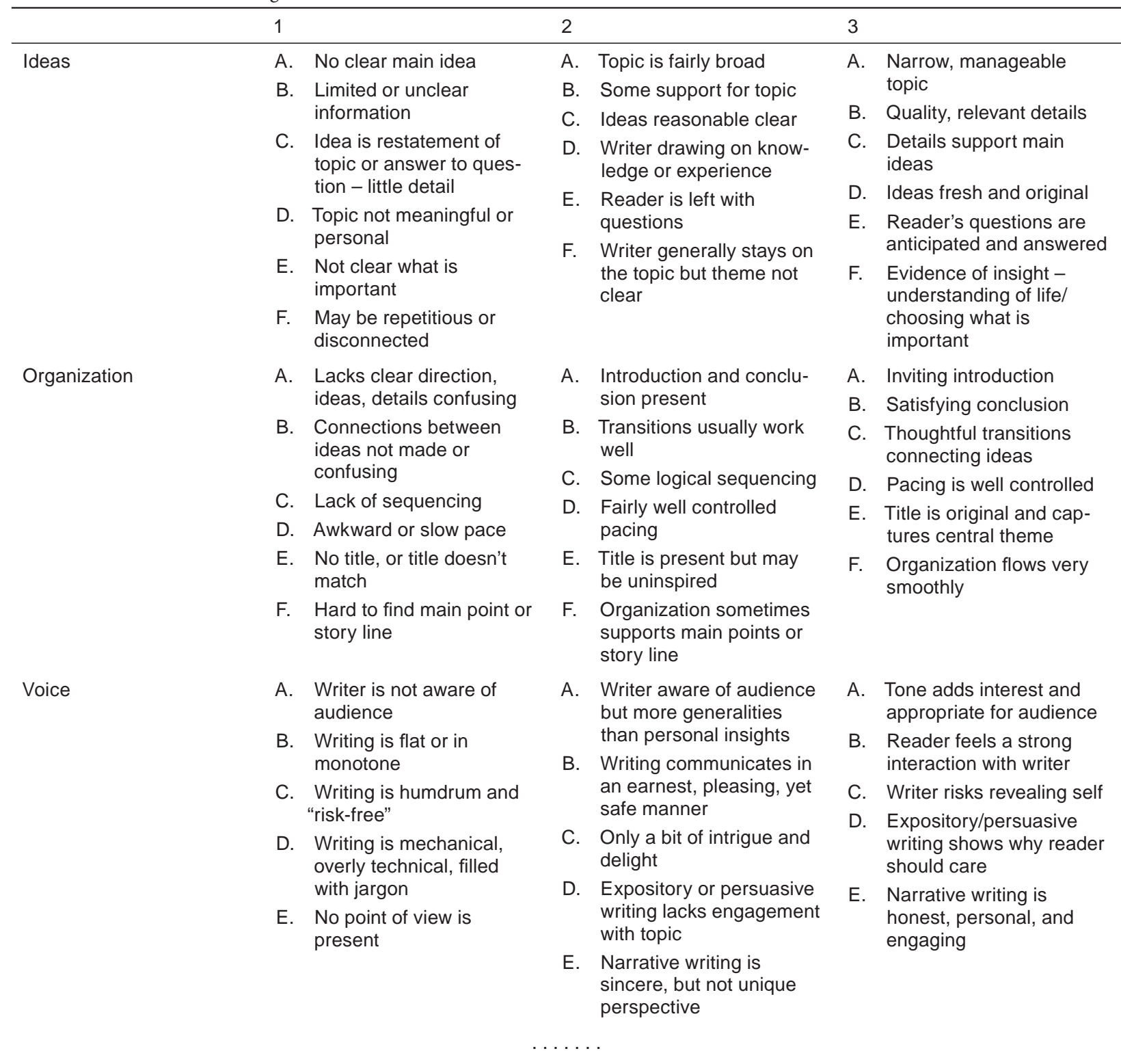




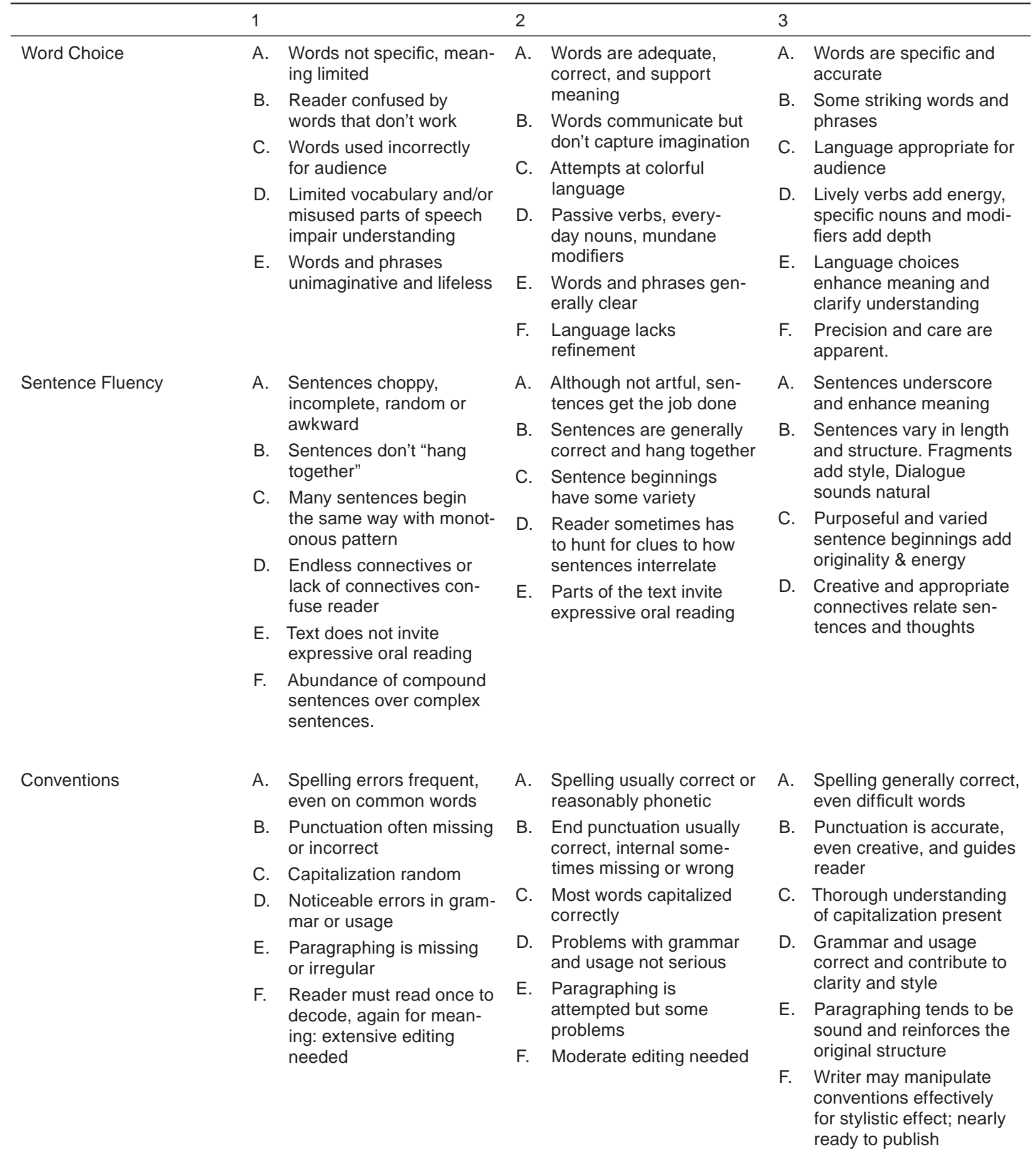

(C) Eric Dwyer and Mary Lou McCloskey, 2013. This open-access work is licensed under a Creative Commons Attribution-NonCommercial 4.0 International License, which permits use, reproduction and distribution in any medium for non-commercial purposes, provided the original author(s) are credited and the original publication in Refuge: Canada's Journal on Refugees is cited. 
Rubric for Six Traits of Writing (cont'd)

\begin{tabular}{|c|c|c|c|c|c|c|}
\hline & 1 & & 2 & & 3 & \\
\hline \multirow[t]{7}{*}{ Presentation } & & $\begin{array}{l}\text { Difficult to read and } \\
\text { understand because of } \\
\text { writing } \\
\text { Writer has used too many }\end{array}$ & A. & $\begin{array}{l}\text { Handwriting readable, } \\
\text { some discrepancies in } \\
\text { shape, form, slant, and } \\
\text { spacing }\end{array}$ & A. & $\begin{array}{l}\text { Handwritten text has con } \\
\text { sistent slant, clear letters } \\
\text { uniform spacing and is } \\
\text { easy to read }\end{array}$ \\
\hline & & $\begin{array}{l}\text { fonts and sizes that dis- } \\
\text { tract the reader }\end{array}$ & B. & $\begin{array}{l}\text { Experimentation with } \\
\text { fonts and sizes somewhat }\end{array}$ & B. & $\begin{array}{l}\text { Word-processed text } \\
\text { uses appropriate fonts } \\
\text { and font sizes }\end{array}$ \\
\hline & & $\begin{array}{l}\text { Spacing is random and } \\
\text { confusing. May be little or } \\
\text { no white space }\end{array}$ & \multirow[t]{2}{*}{ C. } & $\begin{array}{l}\text { successful. } \\
\text { Margins may crowd } \\
\text { edges; spacing applied }\end{array}$ & \multirow[t]{2}{*}{ C. } & \multirow{2}{*}{$\begin{array}{l}\text { White space and format- } \\
\text { ting used to help reader } \\
\text { focus on text }\end{array}$} \\
\hline & \multirow{4}{*}{\multicolumn{2}{|c|}{$\begin{array}{l}\text { D. Lack of markers confuse } \\
\text { reader } \\
\text { E. Visuals do not support } \\
\text { key ideas }\end{array}$}} & & but not best choice & & \\
\hline & & & & An attempt is made to & \multirow[t]{2}{*}{ D. } & \multirow{2}{*}{$\begin{array}{l}\text { Title, side heads, page } \\
\text { numbering, bullets, and } \\
\text { use of style sheet makes } \\
\text { it easy for reader }\end{array}$} \\
\hline & & & & \multirow{2}{*}{$\begin{array}{l}\text { Little evidence of sophisti- } \\
\text { cated formatting to assist } \\
\text { reader }\end{array}$} & & \\
\hline & & & & & $\mathrm{E}$. & $\begin{array}{l}\text { Effective integration of } \\
\text { text and illustrations and } \\
\text { other graphics }\end{array}$ \\
\hline
\end{tabular}

\section{Appendix}

Note that we offer this rubric, adapted from Culham's $6+1$ Traits of Writing, as evidence of what we did. However, we do not recommend the use of this rubric for ELs unless further detailed revision is made, providing for more gradual improvement in proficiency levels.

\section{Notes}

1. UNHCR (United Nations High Commissioner for Refugees), Statistical Yearbook: Refugees, Asylum-Seekers and Other Persons of Concern: Trends in Displacement, Protection and Solutions (Geneva: UNHCR, 2002).

2. UNHCR, "Education Strategy: 2010-2012" (Geneva: UNHCR, 2009), 36.

3. Accessed September 7, 2013, http://www.acf.hhs.gov/ programs/orr/resource/the-refugee-act.

4. Florida, in fact, has a Department of Education office dedicated to the tracking of English learners. More information regarding this office and its practices may be found at http:// www.fldoe.org/aala/. Georgia similarly has an office dedicated to ESOL/Title III issues; information may be obtained at http://www.doe.k12.ga.us/Curriculum-Instruction-and -Assessment/Curriculum-and-Instruction/Pages/English -to-Speakers-of-Other-Languages-(ESOL)-and-Title-III .aspx.

5. For more information, please see http://www.wida.us.

6. National Reading Panel, "Teaching children to read: An evidence-based assessment of the scientific research literature on reading and its implications for reading instruction," 2000; http://www.nichd.nih.gov/publications/nrp/ report.cfm.

7. J. P. Kincaid, R. P. Fishburne, R. L. Rogers, and B. S. Chissom, Derivation of New Readability Formulas (Automated
Readability Index, Fob Count and Flesch Reading Ease For mula) for Navy Enlisted Personnel, Research Branch Report 8-7 (Millington, TN: Naval Technical Training, US Naval Air Station, Memphis, TN, 1975).

8. P. Carrell, "Readability in ESL," Reading in a Foreign Language 4 (1987): 21-40.

9. S. A. Crossley, J. Greenfield, and D. S. McNamara, "Assessing Text Readability Using Cognitively Based Indices," TESOL Quarterly 42, no. 3 (2008): 475-493.

10. Academic language is described in concept in J. Cummins, Language, Power, and Pedagogy (Clevedon: Multilingual Matters Ltd., 2001). It is teased out word-by-word in A. A. Coxhead, "New Academic Word List," TESOL Quarterly 34, no. 2, Summer (2000): 213-238.

11. Such findings have been reported for years, including in C. A. Harper and E. J. Platt, "Full Inclusion for Secondary School ESOL Students: Some Concerns from Florida, TESOL Journal 7, no. 5 (1998): 30-36.

12. E. J. DeJong and C. A. Harper, "Preparing Mainstream Teachers for English-Language Learners: Is Being a Good Teacher Good Enough?” Teacher Education Quarterly 32, no. 2 (2005): 101-124.

13. For more on English language teaching and differentiated instruction, please see S. Herrera and K. G. Murry, Mastering ESL and Bilingual Methods: Differentiated Instruction for Culturally and Linguistically Diverse (CLD) Students (Boston: Allyn and Bacon, 2005).

14. D. August and K. Hakuta, eds., Improving Schooling for Language-Minority Children: A Research Agenda (Washington, DC: National Academy Press, 1997).

15. D. R. Entwisle, K. L.. Alexander, and L. Steffel, Children, Schools, and Inequality (Boulder: Westview, 1998). 
16J. S. Chall, V. A. Jacobs, and L. E. Baldwin, The Reading Crisis: Why Poor Children Fall Behind (Cambridge, MA: Harvard University Press, 1990).

17. A. M. Werner-Smith and L. B. Smolkin, "An ESL/Bilingual/ Bicultural Pre-Collegiate Program for Southeast Asian Refugee High School Students," Bilingual Research Journal 19, no. 3 \& 4 (1995): 395-408.

18. Angela Carrasquillo and Vivian Rodríguez write of an additive process, where students are respected as coming in with their own education, though such may not be congruent to local senses of schooling. Language Minority Students in the Mainstream Classroom, 2nd ed. (Tonawanda, NY: Multilingual Matters, 2002).

19. F. Trudeau and R. J. Shepherd, "Physical Education, School Physical Activity, School Sports and Academic Performance," International Journal of Behavioral Nutrition and Physical Activity 5, no. 10 (2008), accessed September 24, http://www.ijbnpa.org/content/5/1/10.

20. G. Walker, "Inner-City Soccer SCORES Big," Soccer New England, November 20, 2002, accessed September 24, 2008, http://www.soccernewengland.com/articles/view_article .php?id=11; please also see A. Singh, L. Uijtdewilligen, J. W. R. Twisk, W. van Mechelen,and M. J. M. Chinapaw, "Physical Activity and Performance at School: A Systematic Review of the Literature Including a Methodological Quality Assessment," JAMA Pediatrics 166, no. 1 (2012): 49-55.

21. R. M. Callahan, "Tracking and High School English Learners: Limiting Opportunity to Learn," American Educational Research Journal 42, no. 2 (2005): 305-328.

22. Please see L. N.. Levine and M. L. McCloskey, Teaching Content and Language in Mainstream Classes: One Class, Many Paths, 2nd ed. (Boston: Allyn and Bacon, 2013); please also see Y. Freeman, D. Freeman, and S. Mercuri, "Helping Middle and High School Age English Language Learners Achieve Academic Success," NABE Journal of Research and Practice 1, no. 1 (2005): 110-122.

23. K. S. Cho and S. Krashen, "Acquisition of Vocabulary from the Sweet Valley Kids Series: Adult ESL Acquisition," Journal of Reading 37 (1994): 662-7.

24. N. Zaragoza, Rethinking Language Arts: Passion and Practice (New York: Garland Publishing, 1997); please also see J. K. Klingner and S. Vaughn, “The Helping Behaviors of Fifth Graders while Using Collaborative Strategic Reading during ESL Content Classes," TESOL Quarterly 34, no. 1 (2000): 69-98.

25. M. Tenam-Zemach, "An Analysis of Themes of Environmental Sustainability in the United State Curriculum Science Content Standards" (Ed.D. dissertation, Florida International University, 2007).

26. A. F. Ada and I. Campoy, Authors in the Classroom: A Transformative Education Process (Boston: Allyn and Bacon, 2003; please also see N. Zaragoza and E. Dwyer, Look, I Made a Book (New York: Peter Lang USA Publishing, 2005).
27. William Tierney writes that qualitative research should not only chronicle silenced lives but also challenge the oppressive voices doing the silencing. In William G. Tierney, "Loose Change: The Production of Texts, in Power/Knowledge/Pedagogy: The Meaning of Democratic Education in Unsettling Times, ed. Dennis Carlson and Michael Apple (Boulder, CO: Westview Press, 1998), 264-270.

28. Levine and McCloskey, Teaching Content and Language in Mainstream Classes.

29. See J. C. Greene and V. J. Caracelli, "Defining and Describing the Paradigm Issues in Mixed-Method Evaluation," in Advances in Mixed-Method Evaluation: The Challenges and Benefits of Integrating Diverse Paradigms (New Directions for Evaluation, No. 74, pages 5-17), ed. J. C. Green and V. J. Caracelli (San Francisco: Jossey-Bass, 1997); please also see T. S. Rocco, L. A. Bliss, S. Gallagher, A. Pérez-Prado, C. Alacaci, E. S. Dwyer, J. C. Fine, and N. E. Pappamihiel, “The Pragmatic and the Dialectic: Two Views of Mixed Methods Use in Education," chapter in Handbook of Mixed Methods in Social and Behavioral Research, ed. A. Tashakkori and C. Teddlie (2002), 595-615.

30. S. Kemmis and R. Taggart, "Participatory Action Research: Communicative Action and the Public Sphere, in Strategies of Qualitative Inquiry, ed. N. K. Denzin and Y. S. Lincoln (Thousand Oaks, CA: SAGE Productions, 2007), 271-330.

31. T. Schram, Conceptualizing Qualitative Inquiry: Mindwork for Fieldwork in Education and the Social Sciences (Upper Saddle River, NJ: Merrill-Prentice Hall, 2003).

32. M. Q. Patton, Qualitative Research and Evaluation Methods (Thousand Oaks, CA: Sage, 2002).

33. C. Clark and A. Foster, "Children's and Young People's Reading Habits and Preferences: The Who, What, Why, Where and When," National Literacy Trust, 2005; accessed June 30, 2008, http://www.literacytrust.org.uk/research/ Reading_Connects_survey.pdf.

34. J. Abedi, "High-Stakes Tests, English Language Learners, and Linguistic Modification," Sunshine State TESOL Journal 6, no. 1 (2007): 1-20.

35. L. A. Bader, Bader Reading and Language Inventory and Reader's Passages and Graded Word Lists (Spiral-Bound) (Upper Saddle River, NJ: Prentice Hall, 2004).

36. B. Gamse, R. Jacob, M. Horst, B. Boulay, and F. Unlu, Reading First Impact Study Final Report (NCEE 2009-4038) (Washington, DC: National Center for Education Evaluation and Regional Assistance, Institute of Education Sciences, US Department of Education, 2008); please also see Colorín Colorado, "Reading in Second and Third Grades," 2007; accessed May 24, 2010, http://www.colorincolorado .org/educators/teaching/secondreading..

37. R. Culham, $6+1$ Traits of Writing (New York: Scholastic, 2003).

38. J. R. Landis and G. G. Koch, “The Measurement of Observer Agreement for Categorical Data, Biometrics 33 (1977): $159-174$ 
39. M. Q. Patton, Qualitative Research and Evaluation Methods (Thousand Oaks, CA: Sage, 2002).

40. N. Giovanni, Sing a Soft Black Song (New York: Farrar, Straus and Giroux, 1987), 25.

41. A. U. Chamot and J. M. O'Malley, The CALLA Handbook: Implementing the Cognitive Academic Language Learning Approach (White Plains, NY: Addison Wesley Longman, 1994); please also see L. N. Levine and M. L. McCloskey, Teaching English Language and Content in Mainstream Classes: One Class, Many Paths (Boston: Pearson, 2013).
Eric Dwyer is Associate Professor in the Department of Teaching and Learning, Florida International University, Miami, Florida. Mary Lou McCloskey is Director of Teacher Development and Curriculum Design at Educo, Atlanta, Georgia. author(s) are credited and the original publication in Refuge: Canada's Journal on Refugees is cited. 
(C) Eric Dwyer and Mary Lou McCloskey, 2013. This open-access work is licensed under a Creative Commons Attribution-NonCommercial 4.0 International License, which permits use, reproduction and distribution in any medium for non-commercial purposes, provided the original author(s) are credited and the original publication in Refuge: Canada's Journal on Refugees is cited. 